\title{
Bengkulu's Traditional Games for Young Children
}

\author{
Ice Purnawanti Puspitasari ${ }^{1, *}$, Yeni Rachmawati ${ }^{2}$, Nur Faizah Romadona ${ }^{3}$, Ica \\ Purnamasari $^{4}$
}

\author{
${ }^{1,2,3}$ Early Childhood Education, Universitas Pendidikan Indonesia, Bandung, West Java, 40154, Indonesia \\ ${ }^{4}$ Non Formal Education, Malang State University, Malang, East Java, Indonesia \\ *Corresponding author. Email: yeni_rachmawati@upi.edu
}

\begin{abstract}
Traditional games are the result of past human cultural processes which are rich in local wisdom values. The games are played from generation to generation. They have many benefits, including vehicles and media, to stimulate early childhood development. However, traditional games are slowly starting to be forgotten; children tend to get used to the instant games available on smartphones or devices or other games that can be accessed in the centre of modern games. This habit causes children not to know what traditional games are. This research aimed to describe the existence of traditional games for early age children in Bengkulu. This research employed a literature study method. This study's results are expected to provide awareness to parents, teachers, and the community about the benefits of traditional games in stimulating children's development.
\end{abstract}

Keywords: The existence of traditional games, early age children.

\section{INTRODUCTION}

Traditional games are games played by the community and passed down from generation to generation and result from exploring a local culture that contains educational and cultural values [1]. In general, traditional games are played in groups or at least two people [2]. These games are a means of playing for children. Traditional games have many benefits, including stimulating all aspects of children's development (religious and moral values, physicalmotor, cognitive, language, and social-emotional). In addition, traditional games have positive values, namely honesty, cooperation, sportsmanship, help, responsibility, and discipline [3].

Traditional games make children's interactions with the surrounding environment better so that early childhood can learn and play through traditional games [4]. Through play, early childhood can express all forms of pleasant behaviour without coercion. Play for early childhood is learning. Early childhood is a golden age, which is high sensitivity (sensitive period), which will not come twice. A sensitive period is when children can easily and quickly accept the stimuli given [5]. The existence of the golden age and sensitive period, as adults who have the responsibility for early childhood development, either for parents or caregivers, teachers, or the community must provide proper stimulation for all children's development, one of which is traditional games that have many benefits [6].

However, children at an early age nowadays tend to be accustomed to playing games on devices or other games in modern game centres'. Today, this situation causes children to prefer to play with technology-based games that come from abroad and start leaving traditional games. This condition is reinforced by the increasing number of toy shops selling various toys [7]. Some people in Bengkulu often perceive traditional games as an outdated tradition of a society [8]. They feel proud to provide games as gadgets or modern games from abroad which are now widely sold in shops. In Bengkulu, many traditional games can be played by early-age children without paying much money, including ramai-ramai, singgam, setekuk/congkak, jump rope, and pak pisang.

The decreasing existence of traditional games in society comes from two problems: the first, the way people perceive traditional games, which have been eroded by time. Second, the system of inheritance from generation to generation does not work well. The implication is that this tradition is weakened so that children do not know the types or benefits of traditional games. Thus, traditional games need to be considered so that they can still be played from generation to generation in the future. On the other hand, this article's structure is as follows: the first part is the introduction; the second part explains about play and the essence of play for 
children. Next, the third part, traditional games, has many benefits in stimulating all aspects of early childhood development. Meanwhile, the fourth section explains the existence of traditional games, the types of traditional games, the benefits of traditional games, and the factors that cause traditional games to disappear, and the fifth section is the conclusion of the article.

\section{PLAY FOR YOUNG CHILDREN}

Play is a means for children to express all forms of pleasant behaviour without coercion [9]. Play activities can be done indoors and outdoors [10]. Play and children are two things that cannot be separated because learning in early childhood is playing, and playing is learning. Like two sides of a coin, they depend on each other. Play and games always refer to children; the world of play is known as the world of children. Playing for the early childhood period is learning many things, including socializing, cooperating, managing emotions, understanding rules, and tolerance [11]. Some of the essences of play for early childhood include:

1. Internal Motivation. Children at an early age play on their own accord without being forced.

2. Active. Every time children play, this activity will involve or stimulate physical, motor, and mental.

3. Nonliteral. Children choose games and play according to their own wishes, regardless of the reality of pretending to be playing something.

Before playing, children have no external purpose. The essence of play for children is only participation.

\section{TRADITIONAL GAMES}

\subsection{Definition of Traditional Games}

Traditional games that have existed since our ancestors' days were the result of past human cultural processes that were rich in local wisdom values [12]. Traditional games have developed from a particular community habit adapted to the local area's cultural traditions. The games are more comfortable to do, without expensive costs, without forgetting the surrounding environment, and making children more involved in the interaction with peers [13]. The games have a function or message behind them. Traditional games are cultural products of great value for children in fantasizing, recreation, creativity, sports, and practicing for social life, skills, politeness, and dexterity.

Thus, traditional games are very appropriate for a vehicle and media to provide educational stimulation to achieve educational goals [14]. Through traditional games, children can learn to play strategies, work together in teams or groups, and have fun playing. The games make children's interactions with the surrounding environment better to learn and play through traditional games. Thus, traditional games aim not only to entertain oneself but also to maintain social relations and enrich the nation's culture [15].

\subsection{Benefits of Traditional Games}

Games that must be introduced to children at an early age can stimulate all aspects of development and are fun for children, such as traditional games [16]. Play activities and games for children are not just entertainment, but indirectly (indirect teaching) can develop a positive personality like the values contained in each game [17].

The benefits of playing traditional games for early childhood are:

\section{Development of Religious and Moral Value}

Moral development is the development of thoughts, feelings, and behaviour based on habits that should be done when interacting with other people [18]. Morality for early childhood is an abstract thing. Through play, morals can be introduced to children. For example, before starting playing a game, the first thing to do is introducing rules on how to play, then children follow and obey the rules that have been set. Besides, before playing the children must also read the prayer first, this is where the children's moral development begins to be stimulated.

\section{Motor Development}

When playing games that involve physical activity, children's motor skills will stimulate the development of their fine and gross motor skills. For example, the traditional game sesimbunan (hide and seek), in which children losing are in charge of looking for their friends, and other children are hiding. The child losing will try to find friends who are hiding. In this traditional game, children will walk, run, and bend over to stimulate the child's physical and motor skills [19].

\section{Cognitive Development}

Cognitive is a process of thinking and observing to produce, acquire, and store knowledge [20]. For example, when children are going to play with their friends and make rules together, that is when children build their abstract thoughts and get creative ideas, and build a strong memory.

\section{Language Development}

Language is obtained by children in various ways, including through playing traditional games. During play, children will express their wishes and communicate the language with their friends. That is when children learn the language [21]. 


\section{Social-emotional Development}

Through playing with their friends, children will learn to understand themselves and others and regulate their emotions while playing [22].

\section{BENGKULU'S TRADITIONAL GAMES}

In the past, traditional games were trendy before technology entered Indonesia [23]. Children play using makeshift tools [24]. The types of traditional games that are often played by early age children in Bengkulu include:

\subsection{Ramai-Ramai}

Seven children play this game, and it will be even more fun if more participants play it. The procedures for playing are: (1) children will determine who is guarding (in the middle) through sum/hompimpa (rock-paperscissors). Children with different hand positions will be in charge of guarding. (2) When the children have found the guard, the children will form a circle, then the child who is guarding them will be in the middle of their friends while their eyes are covered with handkerchiefs. (3) Children who form a circle move around the guard while singing the song "ramai-ramai", which is "ramairamai kayak orang buta...si Nana menutup mata, cari kawan sampai dapat hup hup". (4) Children who form a circle and sing will be quiet and stay away from the guard, but the hands are still holding each other in a circle. (5) The guard will look for them by touching their friends and saying their names. (6) If the name mentioned is correct, he/she will be the one who takes the place of guarding in the middle and blindfolded. If what is stated is wrong, then the friends will respond by saying "wrong" and will sing again until the guard finds a friend and correctly mentions his/her friend's name to replace $\mathrm{him} / \mathrm{her}$ as the guard in the middle.

Game "ramai-ramai" can stimulate all aspects of child development.

\section{Religious and Moral Value Development}

Before playing, the children were accustomed to praying. During the play, the children will be patient and honest when the guard mentions the friend's name, and is willing to replace his/her friend to guard.

\section{Motor Development}

While playing, the children would go around the guard. Then the guard will feel, move, and walk to find his/her friend. It is the time the child's fine and gross motor skills are stimulated.

\section{Cognitive Development}

Children who are playing will think about how they cannot be touched and named. Likewise, the child who is on guard will think and try how he/she can find and name his/her friends correctly, by remembering the clothes his/her friends wear, hair, bracelets and so on, this process of thinking and remembering is what makes children's cognitive development develop.

\section{Language Development}

During play, the children will talk to determine who will be guarding what the rules are, and sing the "ramairamai" song. By singing, interacting, and expressing opinions, children's language development will develop.

\section{Social-emotional Development}

The children will work together to agree to follow the game's rules and will play to the end.

\subsection{Pak Pisang}

This game is played by at least 3 children or more. Before playing, the children determine who will point the fingers of their friends by sum/hompimpa (rock-paperscissors) and determine what punishment will be given to their friends who lose. The child whose hand position is different from the other children is in charge of pointing the other members' fingers. The procedures for playing are: (1) the children sit in a circle, then place their hands together with the other friends' hands, (2) the children start playing while singing a song and the child in charge of pointing starts pointing the fingers of his/her friends one by one, (3) the children sing together "pak, pak pisang, pisangku belum masak, masak sebiji bighang baghi cak melicak masuk apai..." (4) the child's finger which is pointed at the end of the song, will get folded and so on until all the members' fingers are all folded, (5) the member's finger who is last folded will gets punishment based on the agreement set before playing, for example singing a song while dancing to the rhythm of the song, (6) the child who gets the punishment replaces the friend who served as a pointer.

The game "pak pisang" can stimulate all aspects of early childhood development:

\section{Religious and Moral Value Development}

Before playing, children are accustomed to praying, when playing the children will be patient, behave politely and accept all the rules of the game that have been determined collectively, obey the rules of the game, be honest when their fingers have to be folded and are willing to accept punishment if their fingers last folded. Being honest, patient, and accepting and obeying the rules will stimulate the development of children's religious and moral values.

\section{Motor Development}

When playing, children will move their hands and fingers to point their friends' fingers. Then the finger that is pointed must be folded. In this game activity, children's motor skills begin to be stimulated. 


\section{Cognitive Development}

Children who play "pak pisang” will think and count how many fingers have not been folded and which have been folded because children whose fingers have not folded the most will get a punishment that has been set beforehand. Thinking and counting, and remembering the names of the fingers that have not been folded indirectly stimulate children's cognition.

\section{Language Development}

Children who play together will sing the "pak pisang" song. Before playing, the children will reveal or suggest what punishment will be given to the child whose fingers have not folded the most. When determining the punishment, the child's language development is stimulated.

\section{Social-emotional Development}

When playing, children can follow all activities, obey the rules of the game, respect their friends' abilities, and are willing to replace their friends as pointers when their fingers have not been folded the most. When the child follows the predetermined rules and plays to the end, the child's social-emotional development is stimulated.

\subsection{Sesimbunan (hide and seek)}

Three or more children play this game. The play procedures are: (1) before playing, the children determine who will guard by doing sum/hompimpa (rock-paperscissors). The children play in a circle, and they move their right-hand upside or down. Children whose hand positions are different from other children will be in charge of guarding. (2) When the penjage (guard) has been elected, the other children hide separately. (3) The guard will close his/her eyes when her friends look for a place to hide. When he/she closes his/her eyes, the guard asks "udim-belom" (ready or not?). If his/her friend answered no, the guard will still close his/her eyes, and if none of his/her friends answered, he/she will start looking for his/her friends. (4) When the guard finds out where his/her friends are hiding, the guard will say, Aldo got it (Suppose the name of the hiding friend found is Aldo). After that, the guard will run to the initial place. Then, the guard will continue to search until all of his/her friends are found. (5) When all of the game members have been found, then the one who will replace the guard's position is his/her friend who was first found.

Sesimbunan games (hide and seek) can stimulate all aspects of a child's development.

\section{Religious and Moral Value Development}

When playing, the child will be patient when he/she has to guard or become a penjage (the guard) to find his/her friends until his position is replaced by his/her friend who was first found. This is a situation where the c5hildren train their patience to find their friends until they are all found.

\section{Motor Development}

In this game, children will walk, run, bend, and look, to find a safe place to hide. Likewise, with children who act as the guard, he/she will try to find his/her friends. When the child plays, the child's motor development will be stimulated.

\section{Cognitive Development}

Having a role as a guard, the child in charge will think, observe where his/her friends are hiding, and try to find them. Besides, the hiding friends also tried to find a safe place so that it is not easy for the guard to find them. Thus, through this activity, children's cognitive development will be stimulated.

\section{Language Development}

During play, children will interact and express how to play, express their wishes, and talk when they already find their friends. That is when children learn the language.

\section{Social-emotional Development}

The children will work together to agree to follow the game's rules and will play to the end.

In Bengkulu, there are many types of traditional games, as mentioned above. These traditional games have many benefits, one of which is to stimulate all aspects of child development. However, children nowadays tend to be accustomed to instant games available on devices like smartphones or other games in modern game centers. Therefore, children prefer to play with technology-based games from abroad and start leaving traditional games. This condition is reinforced by the increasing presence of children's toy shops that sell various toys.

The existence of traditional games is slowly being forgotten by children [25]. There are four factors that cause the loss of the existence of traditional children's games; they are: no place to play, increasingly limited playing time due to the increasingly complex demands for children like extracurricular activities and courses, traditional games are being pushed by modern games from abroad which is more practical and can be played at any time, and there is no need to wait for other people to play, and the interruption of cultural inheritance carried out by previous generations where they did not have time to record, record, and socialize the cultural products of the ancient tradition to the next generation. The "instant" culture that has permeated every member of society now also contributes to the loss of traditional games.

As adults, parents, teachers, and the community should introduce and accustom children to playing traditional games because traditional games have many 
benefits to stimulate child development. These traditional games are easy to play, do not require expensive costs, and can be played with minimal equipment.

\section{CONCLUSION}

The existence of traditional games is increasingly rare; even many young children do not recognize traditional games. They only know about gadgets and modern games. This situation can be seen from the absence of children who play traditional games. Thus, to introduce and preserve traditional games as a medium or a tool to stimulate children's development, all parties must work together to preserve traditional games and culture. The methods are: first, parents should not get their children used to playing gadgets but should introduce traditional games and always provide assistance and guide their children in the learning process to achieve the expected goals. Second, teachers should be more creative in providing learning activities using existing traditional games. Third, education institutions emphasize the use of traditional games to stimulate children's growth and development.

\section{ACKNOWLEDGMENT}

This article is supported by various parties. The author would like to thank the supervisor who always provided unlimited motivation and suggestions, the Institute for Research and Community Service, Universitas Pendidikan Indonesia, and the Indonesian Ministry of Research and Technology.

\section{REFERENCES}

[1] Chaelani I, Febrianta Y, Muslim A. Analisis kebutuhan pengembangan model permainan tradisional Jawa Tengah untuk pembelajaran matematika di sekolah dasar. Jurnal Pendidikan Jasmani dan Keolahragaan. 2019;2(1):155-63.

[2] Pratiwi W. Konsep bermain pada anak usia dini. TADBIR: Jurnal Manajemen Pendidikan Islam. 2017;5(2):106-17.

[3] Kovačević T, Opić S. Contribution of traditional games to the quality of students' relations and frequency of students' socialization in primary education. Croation Journal of Education. 2014;16(1):95-112.

[4] Atinia Yahman EK, Ika Sari Rakhmawati NU. Pengaruh permainan tradisional gobak sodor modifikasi sebut kata terhadap kemampuan mengenal kata anak usia 5-6 tahun di Surabaya. Paud Teratai. 2019;8(2):1-9. Available from: https://jurnalmahasiswa.unesa.ac.id/index.php/paud -teratai/article/view/28729/26302.

[5] Sulistyaningtyas RE, Fauziah PY. Pengembangan buku panduan permainan tradisional untuk meningkatkan kemampuan motorik kasar anak usia 5-6 tahun. JPPM (Jurnal Pendidikan dan Pemberdayaan Masyarakat). 2019;6(1):50-8.

[6] Nurhayati I. Peran permainan tradisional dalam pembelajaran anak usia dini (studi di paud geger sunten, desa suntenjaya). Empowerment: Jurnal Ilmiah Program Studi Pendidikan Luar Sekolah. 2012;1(2):39-48.

[7] Lindawati YI. Faktor-faktor penyebab eksistensi permainan tradisional di desa nyangkringan. Hermeneutika: Jurnal Hermeneutika. 2019;5(1):1324.

[8] Maricar F, Tawari RS. Nilai dan eksistensi permainan tradisional di Ternate. Etnohistori: Jurnal Ilmiah Kebudayaan dan Kesejarahan 2018;5(2):162-84.

[9] Rohmah N. Bermain dan pemanfaatannya dalam perkembangan anak usia dini. Tarbawi: Jurnal Pendidikan Islam. 2016;13(2):27-35.

[10]Holis A. Belajar melalui bermain untuk pengembangan kreativitas dan kognitif anak usia dini. Jurnal Pendidikan UNIGA. 2017;10(1):23-37.

[11] Mulyasa Manajemen PAUD. Bandung: PT Remaja Rosdakarya; 2014.

[12] Nadziroh N, Chairiyah C, Pratomo W. Nilai-nilai karakter dalam permainan tradisional TRIHAYU: Jurnal Pendidikan Ke-SD-an. 2019;5(3). Available from: http://dx.doi.org/10.30738/trihayu.v5i3.6119.

[13] Hadi P, Sinring A, Aryani F. Pengaruh permainan tradisional dalam meningkatkan keterampilan sosial siswa SMP. Jurnal Kajian Psikologi Pendidikan dan Bimbingan Konseling. 2018;4(1):32-7. Available from: http://dx.doi .org/10.26858/jpkk.v4i1.4474.

[14] Kusmiati AM, Sumarno G. Pengaruh permainan tradisional terhadap kemampuan perseptual motorik anak di SDN Margawatu II Garut Kota. TEGAR: Journal of Teaching Physical Education in Elementary School. 2018;1(2):17-23. Available at: http://ejournal.upi.edu/index.php/tegar/index.

[15]Tedi W. Perubahan jenis permainan tradisional menjadi permainan modern pada anak-anak di Desa Ijuk Kecamatan Belitang Hulu Kabupaten Sekadau. Jurnal Sl Sosiologi. 2015;3(4):1-17.

[16] Munawaroh H. Pengembangan model pembelajaran dengan permainan tradisional engklek sebagai sarana stimulasi perkembangan anak usia dini. Jurnal Obsesi: Jurnal Pendidikan Anak Usia Dini. 2017;1(2):86-96. Available from: doi: 10.31004/obsesi.v1i2.19.

[17] Setiani RE. Pemanfaatan permainan tradisional dalam penanaman nilai-nilai kebangsaan di TK Negeri Pembina 2 Purwokerto. Aș-Șibyān: Jurnal Pendidikan Anak Usia Dini. 2019;4(1):39-52. 
[18] Pamungkas, J. Stimulasi perkembangan nilai-nilai agama dan moral pada anak usia dini melalui estetika gerak permainan tradisional masyarakat Yogyakarta. Jurnal penelitian ilmu pendidikan. 2015;8(2):1-9. Available at: https://doi.org/10. 21831/jpipfip.v8i2.8265.

[19] Hasanah U. Pengembangan kemampuan fisik motorik melalui permainan tradisional bagi anak usia dini. Jurnal Pendidikan Anak. 2016;5(1):71733. Available from: https://doi.org/10. 21831/jpa.v5i1.12368.

[20]Heryanti V, Wembrayarli W, Hadiwinarto H. Meningkatkan perkembangan kognitif anak melalui permainan tradisional (Congklak) [Doctoral dissertation, Universitas Bengkulu]; 2014.

[21] Khasanah I, Prasetyo A, Rakhmawati E. Permainan tradisional sebagai media stimulasi aspek perkembangan anak usia dini. PAUDIA: Jurnal Penelitian dalam Bidang Pendidikan Anak Usia Dini. 2011;1(1):91-105. Available from: https://doi.org/10.26877/paudia.v1i1.261.

[22] Mukhlis A, Mbelo FH. Analisis Perkembangan sosial emosional anak usia dini pada permainan tradisional. preschool: Jurnal Perkembangan dan Pendidikan Anak Usia Dini. 2019;1(1):11-28.

[23] Robiah LS. Pengaruh eksistensi permainan tradisional terhadap sistem sosial masyarakat: Studi di Kampung Paledang Desa Cileunyi Wetan Kecamatan Cileunyi Kabupaten Bandung [Doctoral dissertation, UIN Sunan Gunung Djati Bandung]; 2018. Available from: http://digilib.uinsgd.ac.id/id/eprint/13665.

[24] Saputra NE, Ekawati YN. Permainan tradisional sebagai upaya meningkatkan kemampuan dasar anak: Jurnal Psikologi Jambi. 2017;2(2):47-53.

[25] Mariani NN. Internalisasi permainan tradisional pada pelajaran seni budaya dan prakarya untuk membangun karakter anak sekolah dasar. Adi Widya: Jurnal Pendidikan Dasar. 2019;2(1):49-55. 